Acta Universitatis Wratislaviensis No 3920

Anglica Wratislaviensia LVII, Wrocław 2019

DOI: 10.19195/0301-7966.57.11

\author{
Amanda Roig-Marín \\ ORCID: 0000-0003-1397-7163 \\ University of Cambridge \\ adr41@cam.ac.uk
}

\title{
Challenges in the Study of "Spanish" Loanwords in Late Medieval and Early Modern English
}

\begin{abstract}
The study of copious Latin and French loanwords which entered the English language in the Middle Ages and the early modern period has tended to eclipse the appreciation of more limitedyet equally noteworthy - lexical contributions from other languages. One of such languages, Spanish, is the focus of this article. A concise overview of the Spanish influence on English throughout its history will help to contextualize a set of lexicographical data from the $O E D$ which has received scant attention in research into the influence of Spanish on English, that is, lexis dating to the late medieval and early modern period. It re-evaluates the underlying Arabic influx in English common to Spanish and revisits some of the lexicographical challenges in tracing the etymology of words which could have potentially been borrowed from a range of Romance languages.
\end{abstract}

Keywords: Spanish, Arabic, loanwords, Late Medieval English, Early Modern English

\section{Spanish words in English: Past and present}

General surveys of the history of the English language usually give a sample of Spanish loanwords in passing and along with European languages other than French and Latin, which are discussed more lengthily and often in self-standing sections. Baugh and Cable (10) list only ten Spanish-origin lexical items without further comments (i.e. alligator, cargo, contraband, cork, hammock, mosquito, sherry, stampede, tornado, and vanilla). Barber (181-182) minimizes the presence of Romance languages in Early Modern English by stating that only "a few words" were imported from Italian and Spanish, specifically those from the trading and warfare realms (he cites anchovy, armada, cargo, and sherry from Spanish) and, after the arrival of the Europeans in America, novel concepts associated with what was an entirely new continent to them (cockroach, potato, cannibal, and mosquito, 
which may tentatively come from either Portuguese or Spanish) (cf. Barber 182). Nevalainen (371) does highlight that the languages that contributed the most to Early Modern English (after Latin and French) are Greek, Italian, Spanish, and Dutch, even though they only amount to less than ten per cent of the total loanword stock during that period; in a footnote, she also glosses the percentages corresponding to each language: "both Spanish and Dutch borrowing remain below the five per cent level" but, she adds, "there is a minor peak for Spanish at the beginning of the seventeenth century" (455). This peak can be contrasted with the Oxford English Dictionary $(O E D)$ data, but for now it is worth stressing that in her overall account more than 40 loanwords from Spanish are enumerated (Nevalainen 372-373; also cf. Scheler 64).

An earlier work which exclusively tackles Spanish-origin words is RodríguezGonzález's Spanish Loanwords in the English Language. Albeit with a predominantly synchronic approach, this volume covers well historical aspects (Rodríguez González, "Introduction" 3-4; Algeo 13-40; Cannon 41-60). Among its chapters, Algeo's (13-40) survey of Spanish loanwords up to the 20th century, based on the current edition of the $O E D$ back then (OED2), paved the way for future historically-oriented contributions. A more concise discussion of Spanish-origin material (lexemes and, to a lesser extent, morphemes) in the course of the English language can be found in Durkin's monograph on loanwords. ${ }^{1}$ He overviews the influx of Spanish borrowings from the Middle English period to the 20th century, mostly by drawing on the on-going work for the $O E D 3$; he only pinpoints two plausible examples in Middle English (cork and fustic) and singles out the case of the very late Middle English marmalade, which seems to have been borrowed directly from Portuguese (Spanish mermelada [1570] is recorded later). In reference to the Middle Ages and the broader multilingual context that conspicuously characterized medieval Europe, Conde (89-95) documents the fascinating history of two words from Mozarabic (the Romance language variety that was employed in central Iberia after the Arab conquest) which made their way into Middle English: Spanish-Arabic corcho/corcha and cordoban/cordovan > English cork and cordwain and the derivative agent noun cordwainer. I will concentrate on the common Arabic substratum of some borrowings in the $O E D$ in Section 3.

Unlike Nevalainen, Durkin (365) notes a more remarkable increase in Spanish loanwords earlier that the 17th century, particularly from 1550 to 1650 , which reflects the prosperity of Spain during the period that is commonly known as its

${ }^{1}$ A thorough (yet much earlier) discussion of this can also be found in Serjeantson (195-202), which includes a general overview of Spanish loanwords in the history of English as well as lists of loanwords (from 1500 to 1800) classified under the following headings: "Spanish trade and products", "words denoting persons and titles of rank", "games and dancing", "naval and military", "miscellaneous", and "words from America". 
Golden Age. ${ }^{2}$ Muñoz-Basols and Salazar (85) quantitatively confirm the growing influx of Spanish over the 16th and 17th centuries (the $O E D$ attests to 260 Hispanicisms in 16th-century English and 313 in the 17th century). Afterwards, there is an overall decline in numbers until the early 19th century, when this trend is again reverted, possibly as an outcome of a greater Spanish and English contact in America. ${ }^{3}$ Schultz's recent book (The Influence of Spanish on the English Language since 1801) precisely concentrates on the influence of Spanish on English vocabulary after that period. Apart from the lexicographical evidence provided in the $O E D$ - a common source to Algeo's and Durkin's investigations - the use of English corpora (viz. the BNC, the Now Corpus, the COCA, and LexisNexis) underpins her work. "The chronological distribution, semantics, stylistic function, and contextual usage" (Schultz, "The Impact" 11) of that lexical material is, therefore, situated in present-day English. The methodological procedure adopted in the former investigation is replicated in her chronologically narrower analysis of those Spanish-origin lexemes entering the language from 1901 to the present time, which amount to 525 words and meanings. She classifies the data into broad semantic categories, "people and everyday life" and "gastronomy" proving the most popular ones by a relatively narrow margin ( $20.8 \%$ and $17.3 \%$ of the total respectively). ${ }^{4}$

The present-day panorama continues to be mostly dominated by Spanish-English contact scenarios in the United States (see Rodríguez González's contributions), as reflected in the geographical use of what the OED classifies as Spanish-origin words or words having Spanish as a probable or likely source of input. Out of the 1,808 words recorded in the $O E D$ as potential Spanish-origin lexemes (including 15 labelled as "archaic", 145 "historical", and 2 "disused"), 230 of them originated or are chiefly used in the United States; and, even if 40 of them are labelled as "rare", they surpass the diatopically marked usage of Spanish-origin words in the other regions - even as far as whole continental areas - in the OED: Africa (6), Australasia (11), Britain and Ireland (8), Caribbean (35), India (1), Canada (2), and South-East Asia (18). Over the last decade, only two lexical items from Spanish have been added to the OED (OED [2010], s.v. REGGAETON and GALACTICO, the latter one coming from peninsular Spanish). Nonetheless, as can

2 Prior to 1550 , the first part of the 16th century witnessed a slight increase in borrowings from Ibero-Romance languages (mostly from Spanish, but also from Catalan and Portuguese). See Durkin (365).

${ }^{3}$ Both Spanish and French loanwords in Caribbean English merit further attention, as Allsopp's article evidences.

${ }^{4}$ Note that each of these subject fields in Schultz contains an array of sub-sections which may not be transparently related to the broader category (e.g. "people and everyday life" encompasses "habitation and buildings", "monetary units", "transport and travelling", "fashion, clothing, footwear and accessories", "agriculture, animal husbandry, farming and horseriding", "communication", and "society, human behaviour characteristics and feelings"). That is why I refer the reader to Schultz ("The Impact" 27-28) for a clearer idea of the precise semantic distribution into which more recent Spanish borrowings fall. 
be inferred from the overall data in the $O E D$, this cannot be taken as an indicative measure of the full dimensions of the presence of Spanish in English. Further research in the coming years would very likely trace new "Hispanicisms" in the $O E D$, but they lie outside the scope of the present article, which is limited to the medieval and early modern periods.

\section{Methodological considerations}

For preliminary searches, I made use of the advanced search option available in the online version of the $O E D$. I selected Spanish as the "language of origin" and initially limited the timespan to the Middle Ages. The results yielded were, nevertheless, highly controversial and could not be accepted as bona fide Spanish-origin lexemes (see Section 3). I then performed a second search which attempted to gauge the impact of Arabic - and, more specifically, Spanish-Arabic - on English over a relatively broader time span: $1300-1700$. This decision was motivated by the historical significance of Arabic knowledge and culture well after the Middle Ages. The data was then manually collated and processed, and a sample of the most taxonomically challenging results is discussed below. ${ }^{5}$ Given the aim of this article, more straightforward borrowings such as maravedi ("any of a number of medieval Spanish silver coins, distinguished by a 5.5 gram denomination based on an Almoravid silver coinage") (OED, s.v. maravedi $<$ Spanish maravedi, which at the same derives from Arabic $<$ Arabic murābiți , adopted from the noun denoting the Almoravids, (al-)Muräbitūun, the Berber Muslim rulers of Spain from the late 11 th century to the 12th century) or others expressing geographically specific concepts or practices, are not herein considered.

The morphological make-up of the lemma included in the $O E D$ was not taken as the sole factor for assessing the etymology of the word, which is why it was conjointly analyzed with the relative dating in other Romance languages as well as their semantics, if the attestations suggest differing meanings. To this end, I refer to two French dictionaries - namely, the Trésor de la Langue Française informatisé (TLFi) and the Französisches etymologisches Wörterbuch (FEW) - the Diccionario de la Real Academia Española (DRAE), and one of the main diachronic corpora of Spanish, the Corpus diacrónico del español (CORDE).

5 As the online $O E D$ clearly states whether the entry has been revised since it was first created, I include the entry date in parentheses. Likewise, only grammatical information about the lemma is brought to the fore in case of potential ambiguities. Otherwise, n. (noun) is presupposed. 


\section{Spanish in the late medieval and early modern vocabulary of the $O E D$}

Not earlier than 1300 can we find any traces of Spanish recorded in the $O E D$, and only ten lexemes dated from 1300 to 1400 are retrievable by using the "language of origin" search option: ${ }^{6}$ checkmate (a1346), err (1303), fie (v.1, 1340), Aristolochia (a1398), Brazil (n.1, c1386), collyrie (1382), †compense (1393), and valerian (c1386), jujube (c1400), and †scarceler (14??). Surprisingly, none of the early Spanish-origin Middle English words discussed in Durkin (2014) correlate with the results in the $O E D$. Therefore, the data above should be treated very carefully and cannot be adduced to identify Spanish loanwords: all of these entries have not been revised since the first edition of the $O E D$ and, more importantly, the etymology section for them hints at several source languages (post-classical Latin and/or Romance languages such as French, Spanish, Portuguese, Catalan, Occitan, and Italian) without necessarily establishing an unequivocal immediate etymon; lists of cognates and some question marks are indeed recurrent. This proves the difficulties in tracing clear-cut boundaries across medieval languages, particularly so within the same language family or languages in contact. Ever since the first edition of the $O E D$ was published (OEDI), there have been substantial lexicographical advances which have fine-tuned our understanding of the trilingual nature of late medieval England; the $D M L B S, M E D$, and the $A N D$ were released and are now fully available online, and like the $O E D$, the $A N D$ is also currently being revised. Therefore, once $O E D 3$ is completed, we will have a better appreciation of the English language in relation to the other two languages used in late medieval England as well as in running in parallel to - and often interlinked with - the other languages spoken in Europe and beyond.

Bearing all of this in mind, this short article does not intend to revise all the entries containing Spanish in the $O E D$, as this would inevitably result in unnecessary duplicities with the more general and mammoth task of $O E D 3$, but it does attempt to flesh out more general pressing questions and illuminate some ambiguous territory in connection to the $O E D$ references to Spanish. I will take the etymology of two of the aforementioned words as case studies and will attempt to prove how they can be accounted for without necessarily referring to Spanish except for illustrative purposes.

Firstly, the plant name valerian (OED [1916], s.v. VALERIAN, 1) can be enlightening: in the $A N D$, there are only two attestations of it (in its rendering into French, VALERIANE, valerian, valeriene, walerien). The first citation includes a

${ }^{6}$ A total of 1,969 lexical entries can be compiled for the period 1300-1400 if an entry-byentry assessment of the $O E D$ is undertaken. However, this short article does not intend to evaluate all those potential borrowings but rather to raise problematic issues. Furthermore, it is worth mentioning that the "etymology" advanced search option is not available to the general users of the $O E D$ and can only be accessed by its editors and collaborators through its internal interface. 
metalinguistic comment, as it comes from an edition of a technical glossary (Mowat 189): "Valeriana, amantilla ..., benedicta, g[allice] et angl[ice] valeriane", which sets the Latin and vernaculars ("French and English valeriane") rendering side-by-side. This does not rule out the possibility of having been directly borrowed from Medieval Latin rather than via French. Durkin explains that words from French and/or Latin tend to be "much more numerous in the 100-year period 1350-1450 than they are at any other time" (Durkin 262). These two alternatives do not necessarily have to be mutually exclusive, as indicated in the $O E D$ entry in its current state, but Spanish is only mentioned within the parenthetical information as a way of acknowledging that valeriana was - and still is - also present in Spanish and that it shares the same word form as Medieval Latin. Unlike valerian, the etymology of checkmate in the $O E D$ seems to be relatively straightforward but adds another caveat to my discussion: the identification of the remote etymon. It reads as follows,

Middle English chek mat (e chekmat(e, aphetic < Old French eschec mat, eschec et mat, Provençal escat mat, Italian scaccomatto, Spanish jaque y mate, Old Spanish xaquimate, xaque mate, Portuguese xaque mate, < Arabic shäh-mät(a 'the king is dead'. (OED [1889], s.v. checkmate, int. and $n$.).

The ultimate etymon for all of these Romance cognates is traced to Arabic shāh-māt (a (itself coming from Persian shāh-māt). How Arabic shāh-māt (a entered French, that is, if directly or indirectly via another language, is another question. The historical sense of a lingua franca as "a pidgin language drawing its lexicon mainly from the southern Romance languages and formerly used as a trading language" (OED [2013], s.v. LINGUA FRANCA; see also Selbach) resonates with such complex etymological pursuits. Neither can we neglect the crucial cultural importance of Medieval Latin and what would be known as Neo-Latin later on. A case in point is athanor. This alchemical term meaning "a digesting furnace used by the alchemists, in which a constant heat was maintained by means of a tower which provided a self-feeding supply of charcoal. Also fig." (OED [1889], s.v. ATHANOR), coming from Arabic al-tannūr (i.e. the article al- + tannūr 'furnace', ultimately, < Aramaic tannūrā < Akkadian tinūru [m] [cf. DRAE, s.v. ATANOR]), ${ }^{7}$ entered Spanish (as atanor) and English and French (as athanor). Like many other Arabic terms, it was incorporated into Spanish through Hispanic-Arabic attannúr $(<$ Classical Arabic tannūr [DRAE, s.v. ATANOR]), so its transmission is more transparent than its borrowing into French. According to the TLFi (s.v. ATHANOR cf. also the $F E W$, s.v. TANNŪR), French athanor was borrowed from Medieval Latin, albeit rather interestingly, "this process probably took place within the Iberian Peninsula". ${ }^{8}$ The $O E D$ entry for athanor has not been updated since it was first

7 The presence of the Arabic article al-in many of these borrowings shows how an Arabic word was often incorporated into the recipient languages without an awareness of the word's morphological structure or components.

${ }^{8}$ All the translations are my own work. 
published in 1889 , and, therefore, its etymology does not seem to be fully accurate; in particular, its status as a direct loanword from Arabic, as it is currently proposed, proves problematic. I will now revisit the Arabic-origin words included in the $O E D$ whose source is not necessarily clear but may be Spanish at some point in their transmission history.

Of the lexemes that I will consider, alfaqui, alkanet, azoth, resalgar, mandil, Kaffir, and Mameluke, only the entry azoth has not undergone any changes since its publication in 1885 . In the OED, azoth is deemed to be "a corruption (ultimately) of Arabic az-zāūq: see assogue, n.", being thus compared to "French azoth, Spanish azogue". The close formal correspondence between the English and French lexemes could signpost a direct borrowing of the English term from the French etymon, which would, in principle, exclude Spanish azoque from the etymological route of this word. Yet, the TLFi (s.v. AZOTH) traces the French azot ("azoth after the Encyclop. 1751") to Spanish azogue, from Spanish-Arabic Zauq. Not only can we find cognates in Spanish and French, but also in Catalan and Portuguese, açoque and azogue, respectively, whose inclusion in the $O E D$ would give a more accurate indication of the surrounding geographical spread of this Spanish-Arabic $(<$ Arabic) alchemical term.

In the case of resalgar, the OED ([2010], s.v. †RESALGAR) does include the multiple European adoptions of the ultimate Arabic rahj al-gंār: post-classical Latin resalger (1418 in a British source) and resegale, Spanish †resalgar (15th century), Italian †risalgaro (14th or 15th century), Old Occitan risalgal (1397), and Italian risigallo (14th century as risagallo). The fact that post-classical Latin resalger is found in a British source seems to imply that it was the direct etymon; no references to French or other possible intermediary languages are made. The etymologically closely related form realgar is likewise claimed to come from post-classical Latin realgar, which is attested from the "13th cent. in British and continental sources". The $O E D$ indicates that the Middle French, Catalan, Spanish, and Italian forms are later (OED [2008], s.v. REALGAR). Notwithstanding this information, the dates given in the $T L F i$ do not entirely correlate: the $O E D$ dating for French realgar is 1495, whereas the TLFi (s.v. RÉALGAR) dates it to ca. 1300. Similarly, the TLFi puts forward another plausible route for its borrowing: it might have been borrowed into French through either Spanish rejalgar (13th century) or Catalan realgar (end of 13th century), and then it compares it to Medieval Latin realgar (1250). The first English quotations in the $O E D$ (s.v. REALGAR, i.e., a1400 and ?c1425-written by multilingual speakers [at least of French and English]) could well evidence a French mediation, so the possibility remains.

The origin of alkanet has not been clearly delineated either. The OED ([2009], s.v. ALKANET, $n$.) offers the alternative that it may be a borrowing from Arabic; the alleged phrase from which the English lexeme would derive is, nevertheless, ungrammatical (*al-hannat), "as the construct state form hannat- cannot be preceded by the definite article al-", which further complicates the history of this word. As 
the $O E D$ pins down, -et may be interpreted as a Romance suffix expressing the diminutive (e.g. in Old French, Provençal, Old Catalan, and Italian), although the hypothesis that alkanet may come from Spanish alcaneta (first advanced by the NED [1884]) was thought to be hampered by empirical evidence: Spanish alcaneta cannot be historically traced. However, the suffix -eta is productive in Spanish (DRAE, s.v. -ETE, TA), and the alleged stem form, alcana, according to the DRAE, shares the same remote etymon (Spanish Arabic alhinna $<$ Classical hinn $\bar{a}{ }^{\prime}$ ) and core senses as alkanet (cf. ALHEÑA, to which the DRAE crossrefers). If alcaneta is indeed a diminutive from alcana (both of them feminine nouns), it would not be included in dictionaries, which could partly justify why its search in historical dictionaries of Spanish is unfruitful. Another hypothetical source etymon would be Old Catalan alquenat (c1350) "hennaed" (Dietz 557), which would imply a word class as well as a semantic change in its transmission as Middle English alk(e)net which is left unexplained. While Dietz discards its connection with Old French arquenet (1393) or Occitan arcaneta (1397), mainly on the basis of their distinct $<\mathrm{r}>$ spellings, he seems to disregard Anglo-Norman alkenet, attested as a noun in a manuscript source of 1394 (AND, s.v. ALKENET). He suggests a gallicization of the first known attestation of the word in English alkenald ([1343] closer to Medieval Latin alcanna), but the form arquinetta, attested in an insular Latin text a few decades later, in 1380 (see DMLBS, s.v. ALCANETTA), is unaccounted for. Therefore, one cannot simply surmise a direct connection between the Spanish/Catalan and Middle English lexemes on these grounds. Dietz seems to be very categorical in his affirmations of Ibero-Romance borrowings into English (see also his comments on fustic, cordwain (er and cork, the latter two being the object of study of Conde's earlier article, neglected in Dietz's paper), and the case of alkanet only proves how a more flexible approach to etymology is desirable.

Moving into early modern loanwords, alfaqui is implicitly classified as polygenetic: the $O E D$ ([2012], s.v. ALFAQUI) points out that it is "partly a borrowing from Spanish [alfaqui], partly a borrowing from Arabic [al-faqi $h]$ ". The dating in this $O E D$ entry is problematic if one juxtaposes the Spanish and the Portuguese attestations: Portuguese alfaqui is dated to the 13th century and Spanish alfaqui to c. 1300. Had alfaqui been attested earlier in Portuguese than in Spanish, the transmission of this word would be much more obscure. Yet, even the somewhat limited corpus of CORDE is able to provide an earlier date for the Spanish lexeme, namely 1253 (CORDE, ALFAQUI, 64 tokens in 15 documents). In the $O E D$, Italian †alfacqui and French alfaqui are dated to the 16th century and seem to involve an indirect or direct use of Spanish source materials. Remarkably, the entry for French alfaqui in the TLFi seems to merge what in Spanish are two words deriving from distinct etymons: alfaquin "a medical doctor" (from Spanish Arabic alhaki $<$ Classical Arabic hakim) and alfaqui "a wise man expert in the law" (from Spanish Arabic alfaqi < Classical Arabic faqi h), which also signifies "a doctor" albeit understood in the archaic sense of "a learned person". An eventual merger of two 
originally independent forms might have been favoured by the loose semantic connection between these two etymons. Ostensibly, the first lexeme adopted in French (post 1256-76), alfaquin, had a medical usage, and after 1527, alfaqui would have been borrowed with the sense of 'Muslim priest' (TLFi, s.v. ALFAQUI). Whereas the present-day sense of alfaqui in French only denotes a Muslim priest, in Guérin's dictionary (1895) the spelling alfaquin (unlemmatized in the TLFi) was preferred. On the other hand, the English history of alfaqui does not reflect this twofold trajectory; the $O E D$ only lists "chiefly in medieval and early modern Spain: a Muslim cleric, an expert in Islamic law" as its sense, and indeed the first quotation provided (1600) refers to a historical figure, John Andreas, a Mahometan born in Xàtiva who later on embraced Christianity (Baldwin 28), which leaves little room for speculation and allows us to establish a semantic departure from the word's borrowing into Spanish and French. ${ }^{9}$

On mostly semantic grounds, a lexeme that can safely be rejected as being borrowed from Arabic through Spanish/Spanish Arabic at any stage is mandil. The revised entry of the OED ([2000], s.v. †MANDIL) points out that it should be compared with French mendil (1659 in the source translated in quot. 1662 [which is the earliest attestation of this word in the $O E D]$ itself translating a German source [from the year 1656], which has Mendil), Spanish mantele (908), and Spanish-Arabic mandīl (there is a cross-reference to mandill, which indicates that it was modelled on a French lexeme [OED (2000), s.v. $\uparrow$ MANDILL]). It could be argued that French borrowed the term from the earlier Spanish Arabic mandil, but the two 1141-1235 attestations of this word in CORDE indeed reveal that the Spanish lexeme already had a different meaning (cf. DRAE, s.v. MANDIL, which lists all the senses of this word) from its sole sense in English, 'a turban; the cloth used to form a turban'. The $O E D$ refers to the $T L F i$, which accounts for the evolution from $<\mathrm{nt}>$ to $<\mathrm{nd}>$ as a phenomenon in Occitan, more precisely in Gascon (cf. TLFi, s.v. MANDILLE), thereby discarding any connections with the Spanish-Arabic etymon in stark contrast to the FEW.

Two other lexical items attested from the early modern period likewise evince multiple inputs from several European languages, one of them being Spanish: Kaffir and Mameluke. Both entries were relatively recently revised (OED [2016], s.v. KAFFIR and $O E D$ [2000], s.v. MAMELUKE) so that they now better represent the complexities of their transmissions. While Arabic kāfir and mamlük are acknowledged as their ultimate Arabic etymons, attention is also drawn to their uses "via forms in other European languages". The Spanish input in these two cases can be placed at the two ends of the spectrum: cafre seems to be the earliest European input (1521) vis-à-vis Spanish mameluco (1585), which is the latest one. The extent to which Spanish — and, indeed, other European languages - had an impact on the

9 John Andreas is not included in the $O D N B$ or any other biographical dictionaries, which is why no references to more recent resources are made. 
adoption of these two words in English cannot be easily quantified but its perusal serves to elucidate the intricate lexical contacts across Europe and beyond.

\section{Concluding remarks}

In this short article, I have attempted to highlight some of the problems in uncritically accepting linear lexical histories: rarely did words travel from one place to another without making stops along the way. Through the examination of Arabic words exhibiting a Romance, more precisely, Spanish input, I have attempted to reconstruct possible routes of entering the English language in the Middle Ages and the early modern period. French was often the immediate source of the lexeme adopted into English, that is, it used to mediate the transmission of these words, but that was not always the case (see, e.g., alfaqui). The genetic proximity between the Romance languages and post-classical Latin (what has been described as the "Latin-Romance continuum" [Trotter 155]) makes the tracing of words from Spanish and Arabic (often borrowings themselves from Persian or Greek) particularly arduous; the relative dating of lexical items - both in terms of their forms and their meanings - in each of the likely input language sources are often of help, but other factors, such as the use of translations from other languages, cannot be overlooked. The connection of a significant number of medieval and early modern Romance lexemes through Arabic had been scantly discussed, which substantiates the scope of this article. Equally, the analysis of forms such as alfaqui, alkanet, azoth, realgar, mandil, Kaffir, and Mameluke has shown how Spanish contributed, in varying degrees, to the transmission of Arabic-origin lexemes, which have constituted a non-negligible part of the Spanish word-stock from the medieval period up to the present time.

\section{References}

\section{Dictionaries}

Guérin, P. 1895. Dictionnaire des dictionnaires. Lettres, sciences, arts, encyclopédie universelle. Paris: Libraires-imprimeries.

Imbs, P., and B. Quemada (eds.). 1971-1994. Trésor de la langue française: Dictionnaire de la langue du XIXe et XXe siècle (1789-1960). 16 vols. Paris: Gallimard. (TLFi). Retrieved from http://atilf.atilf.fr/tlf.htm. 26 Oct. 2018.

Real Academia Española. 2014. Diccionario de la lengua española. 23rd ed. Madrid: Espasa-Calpe. (DRAE). Retrieved from dle.rae.es. 26 Oct. 2018.

Simpson, J. A. (ed.). 2000-. Oxford English Dictionary Online. Oxford: Clarendon P. (OED). Retrieved from www.oed.com. 26 Oct. 2018.

Stone, L. W., T. B. W. Reid, and W. Rothwell (eds.). 1977-. Anglo-Norman Dictionary. (AND). Retrieved from www.anglo-norman.net. 26 Oct. 2018. 
Wartburg, W. von. 1922-78. Französisches etymologisches Wörterbuch: Eine Darstellung des galloromanischen Sprachschatzes. 25 vols. Basel: Zbinden. (FEW).

\section{Secondary literature}

Algeo, J. 1996. "Spanish Loanwords in English by 1900.” In: Rodríguez González, F. (ed.). Spanish Loanwords in the English Language: A Tendency towards Hegemony Reversal. Berlin: Mouton de Gruyter, 13-40.

Allsopp, J. 1992. "French and Spanish Loan Words in Caribbean English." English Today 8.1. $12-20$.

Baldwin, C. N. 1826. Universal Biographical Dictionary. Richmond, VA: Normand White.

Barber, C. 1993. The English Language: A Historical Introduction. 2nd ed. Cambridge: Cambridge UP. Baugh, A. C., and T. Cable. 2002. A History of the English Language. 5th ed. London: Routledge.

Cannon, G. 1996. "Recent Borrowings from Spanish into English.” In: Rodríguez González, F. (ed.). Spanish Loanwords in the English Language: A Tendency towards Hegemony Reversal. Berlin: Mouton de Gruyter, 41-60.

Conde, J. C. 1998. "Spanish Words in Medieval English Lexicon: Sources and Problems." Selim 8. 91-100.

Dietz, K. 2007. "Das frühe iberoromanische Lehngut des Englischen.” Anglia 124. 549-80.

Durkin, P. 2014. Borrowed Words: A History of Loanwords in English. Oxford: Oxford UP.

Mowat, J. L. G. 1887. Alphita, a Medico-Botanical Glossary from the Bodleian Manuscript, Selden B.35. Oxford: Clarendon P.

Muñoz-Basols, J., and D. Salazar. 2016. "Cross-Linguistic Lexical Influence between English and Spanish." Spanish in Context 13.1. 80-102.

Nevalainen, T. 2000. "Early Modern English Lexis and Semantics." In: Lass, R. (ed.). The Cambridge History of the English Language, Vol. III. Cambridge: Cambridge UP, 332-458.

Real Academia Española. 2004. Corpus diacrónico del español. (CORDE). Retrieved from corpus. rae.es/cordenet.html. 26 Oct. 2018.

Rodríguez González, F. 1995. "Spanish Influence on English Word-Formation: The Suffix -ista." American Speech 70.4. 421-429.

—. 1996. "Introduction.” In: Rodríguez González, F. (ed.). Spanish Loanwords in the English Language: A Tendency towards Hegemony Reversal. Berlin: Mouton de Gruyter, 1-12.

—. 2001. "Spanish Contribution to American English Word-Stock: An Overview." Atlantis 23.2. 83-90.

Scheler, M. 1977. Der englische Wortschatz (Grundlagen der Anglistik und Amerikanistik 9). Berlin: Schmidt.

Schultz, J. 2018a. "The Impact of Spanish on English Vocabulary since 1901.” English Today 34.1. 26-31.

—. 2018b. The Influence of Spanish on the English Language since 1801. Newcastle: Cambridge Scholars Publishing.

Selbach, R. 2017. “On a Famous Lacuna: Lingua Franca the Mediterranean Trade Pidgin?” In: Wagner, E.-M., B. Beinhoff and B. Outhwaite (eds.). Merchants of Innovation: The Languages of Traders. Boston: Mouton de Gruyter, 252-271.

Serjeantson, M. S. 1935. A History of Foreign Words in English. London: Kegan Paul, Trench \& Trübner.

Trotter, D. 2009. "Stuffed Latin: Vernacular Evidence in Latin Documents." In: Wogan-Browne, J., C. Collette, M. Kowaleski, L. Mooney, A. Putter and D. Trotter (eds.). Language and Culture in Medieval Britain: The French of England c. 1100-c. 1500. York: York Medieval P, 153-63. 